\title{
COMBINAÇÃO DO EXERCÍCIO FISICO E RAÇÃO HIPOCALORICA PARA TRATAR A OBESIDADE DE CÃES GUIAS
}

Apresentação: Relato de Experiência

Vitor Magalhães de Mendonça Cunha Miranda ${ }^{1}$; Letícia Aline Lima da Silva²; Tayara Soares Lima $^{3}$

\section{Introdução}

O cão-guia é responsável por auxiliar um deficiente visual a se locomover à qualquer lugar e, por estar a trabalho, deve ser aceito em locais públicos, assim a responsabilidade de um cão-guia é bastante séria, então o animal é rigorosamente treinado.Os cães-guias oferecem aos seus parceiros segurança na locomoção, equilíbrio físico e emocional, facilitam sua socialização, e até sua autoestima melhora.

A obesidade trata-se de uma condição patológica caracterizada por um acúmulo de gordura maior que o necessário para a otimização das funções do corpo, suficiente para deteriorá-las e prejudicar a boa saúde e o bem-estar animal (Guimarães andTudury, 2006). Em cães, ocorre quando o peso está pelo menos 15\% acima do ideal (Aptekmann et al., 2014).Para o treinamento do cão guia os animais devem estar em condições de saúde adequadas, muitas vezes os animais estão com o peso elevado devido a uma má alimentação, o que interrompe seu treinamento, visto que a obesidade pode afetar diretamente nas articulações dos animais.

\section{Relato de Experiência}

No Kennel Club do Estado de Pernambuco localizado no Bairro de Jardim Paulista, Paulista, Km 15,5 e tem como acesso a BR 101, possui o projeto do cão guia, porém, os animais estavam acima do peso, assim não podendo participar do treinamento, assim precisando perder peso.

Foi feito o ajustar da alimentação que era fornecida a cada animal. Os animais foram pesados e através do seu peso foi calculada a exigência de energia metabolizável de cada animal: $\mathrm{EM}=\mathrm{PV}^{0,75} \mathrm{X} 130 \mathrm{Kcal}$. Para descobrir o quanto (g) o animal precisava consumir de ração por dia. Dividiu-se a necessidade de EM do cão pela EM da ração, que estava contida no rotulo, sendo 3873 $\mathrm{Kcal} / \mathrm{Kg}$ nas rações para filhote; $3963 \mathrm{Kcal} / \mathrm{Kg}$ para adultose $3873 \mathrm{Kcal} / \mathrm{Kg}$ para cães obesos. Para os

\footnotetext{
${ }^{1}$ Zootecnia, UFRN, vitorzootec01@gmail.com

${ }^{2}$ Zootecnia UFRPE, leticiaaline07@outlook.com

${ }^{3}$ Doutora, UFRPE, tayara.lima@ufrpe.br
} 
animais que estavam acima do peso foi necessário fazer uma restrição alimentar de $40 \%$ para promover a perda de peso.

A ração era fornecida fracionada, duas vezes ao dia, e recalculada conforme o peso que o animal apresentasse na presente semana. A água era trocada todos os dias e fornecida à vontade. $\mathrm{Na}$ primeira semana de estágio iniciou-se o trabalho o exercício consistia em caminhadas que eram divididas em dois períodos que totalizavam 30 minutos por dia. Na Segunda semana foi adicionado ao processo de caminhada o uso de uma bola que era acrescido para fazê-los correr, o que era importantíssimo para os animais obesos, e este momento era acrescido ao fim da caminhada quando já estavam na área reservada aos cães e tratadores em geral. Durante a terceira semana foi incluído um outro fator, pois foi visto que eles ficavam muito ansiosos quando outros brincavam com a bola e decidiu-se soltar todas as fêmeas.

Ao longo dois três meses foi possível observar que os animais perderam pesos e assim começaram a realizar o treinamento do cão guia.

Imagem 1: Atividade com os Cães. Fonte: Própria

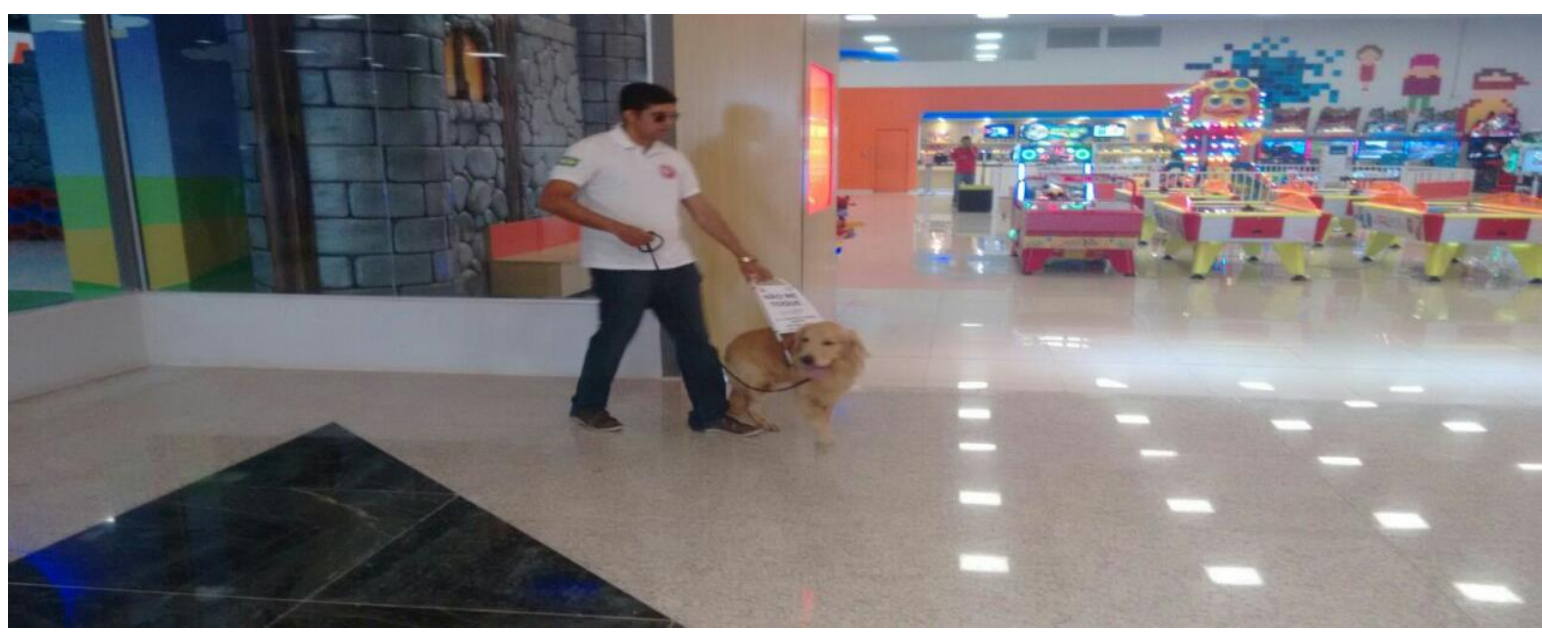

\section{Considerações}

O exercício físico ligado a uma dieta hipocalórica fracionada são técnicas eficazes no tratamento de obesidade em cães. Desde que o proprietário se comprometa ao objetivo da perda de peso do cão, seguindo rigorosamente a dieta hipocalórica nas frações determinadas por dia para o sucesso do tratamento e que os animais não parem de realizar os exercícios.

\section{Referências}

GUIMARÃES, A. L. N. \& TUDURY, E. A. 2006. Etiologias, conseqüências e tratamentos de obesidades em cães e gatos-revisão. Veterinária Notícias, 12, 29-41

GUIMARÃES, A. L. N. \& TUDURY, E. A. 2006. Etiologias, consequências e tratamentos de obesidades em cães e gatos-revisão. Veterinária Notícias, 12, 29-41 